\title{
Influence of regional precipitation patterns on stable isotopes in ice cores from the central Himalayas
}

\author{
H. Pang ${ }^{1}$, S. Hou ${ }^{1}$, S. Kaspari ${ }^{2}$, and P. A. Mayewski ${ }^{3}$ \\ ${ }^{1}$ Key Laboratory of Coast and Island development of Ministry of Education, School of Geographic and Oceanographic \\ Sciences, Nanjing University, Nanjing 210093, China \\ ${ }^{2}$ Department of Geological Sciences, Central Washington University, Ellensburg, WA 98926, USA \\ ${ }^{3}$ Climate Change Institute and Department of Earth Sciences, University of Maine, Orono, ME 04469, USA
}

Correspondence to: S. Hou (shugui @ nju.edu.cn)

Received: 17 April 2013 - Published in The Cryosphere Discuss.: 2 May 2013

Revised: 22 January 2014 - Accepted: 24 January 2014 - Published: 25 February 2014

\begin{abstract}
Several ice cores have been recovered from the Dasuopu (DSP) Glacier and the East Rongbuk (ER) Glacier in the central Himalayas since the 1990s. Although the distance between the DSP and the ER ice core drilling sites is only $\sim 125 \mathrm{~km}$, the stable isotopic record $\left(\delta^{18} \mathrm{O}\right.$ or $\left.\delta \mathrm{D}\right)$ of the DSP core is interpreted in previous studies as a temperature proxy, while the ER core is interpreted as a precipitation proxy. Thus, the climatological significance of the stable isotopic records of these Himalayan ice cores remains a subject of debate. Based on analysis of regional precipitation patterns over the region, we find that remarkable discrepancy in precipitation seasonality between the two sites may account for their disparate isotopic interpretations. At the ER core site, the Indian summer monsoon (ISM) precipitation is dominating due to topographic blocking of the moisture from westerlies by the high ridges of Mt. Qomolangma (Everest), which results in a negative correlation between the ER $\delta^{18} \mathrm{O}$ or $\delta \mathrm{D}$ record and precipitation amount along the southern slope of the central Himalayas in response to the "amount effect". At the DSP core site, in comparison with the ISM precipitation, the wintertime precipitation associated with the westerlies is likely more important owing to its local favorable topographic conditions for interacting with the western disturbances. Therefore, the DSP stable isotopic record may be primarily controlled by the westerlies. Our results have important implications for interpreting the stable isotopic ice core records recovered from different climatological regimes of the Himalayas.
\end{abstract}

\section{Introduction}

The Himalayas impact regional and even global climate due to their high elevation and large topography; however, climate research over the Himalayas is restricted owing to the lack or short duration of meteorological observations because of complex and challenging topographic conditions. Nevertheless, the Himalayas feature the largest volume of ice outside the polar regions, and can preserve high-resolution and long-term climate and environment information, ascribed to their low temperatures and relatively high snow accumulation. To reconstruct climatic and environmental information of the past in the central Himalayas, several ice cores were recently retrieved from the Dasuopu (DSP) Glacier $\left(28^{\circ} 23^{\prime} \mathrm{N}, 85^{\circ} 43^{\prime} \mathrm{E} ; 7200 \mathrm{~m}\right.$ a.s.1.), Shishapangma (Thompson et al., 2000b; Davis et al., 2005) and the East Rongbuk (ER) Glacier $\left(28.03^{\circ} \mathrm{N}, 86.96^{\circ} \mathrm{E}\right.$; $6518 \mathrm{~m}$ a.s.l.), and on Mt. Qomolangma (Everest) (Hou et al., 2000, 2003; Kaspari et al., 2007) (Fig. 1). The dating of these cores can go back to the past $2000 \mathrm{yr}$, with a time resolution from annual scales for the upper part of ice core to decadal for the lower part (Xu and Yao, 2001; Hou et al., 2004). Invaluable climatic and environmental information in the central high Himalayas has been revealed by these ice cores, such as regional warming (Thompson et al., 2000b; Hou et al., 2007), atmospheric pollution induced by anthropogenic activities since the industrial revolution (Duan et al., 2007; Kaspari et al., 2009b; Hong et al., 2009), precipitation variations over the central Himalayas (Duan et al., 2004; Kaspari et al., 2008), atmospheric dust deposition over the past several 
(a)

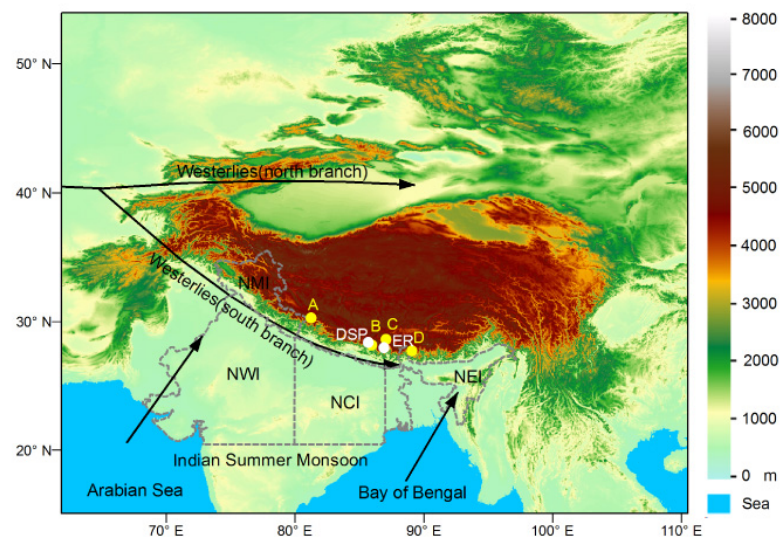

(b)

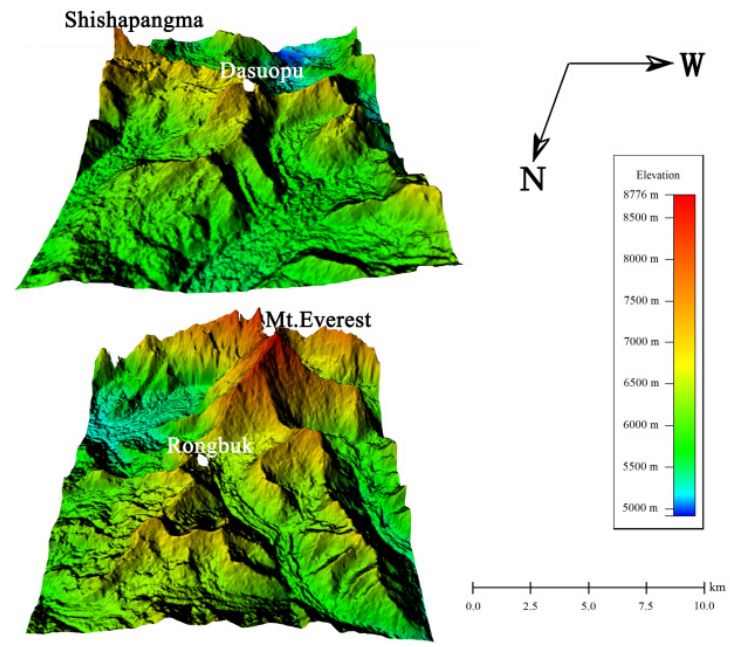

Fig. 1. Atmospheric circulation systems over the study area (a), and three-dimensional topographic maps of the DSP and ER glaciers (b). Filled yellow circles indicate weather stations (A: Pulan; B: Nyalam; C: Dingri; D: Pali), and the filled white circles are the DSP and ER ice core drilling sites. The grey dashed lines are boundaries of the four Indian homogenous rainfall regions north of $21^{\circ} \mathrm{N}$ (i.e., NEI: northeastern India; NCI: north-central India; NWI: northwestern India; NMI: northern mountainous India). Boundary lines are for reference only and may not denote actual political borders. Digital elevation model (DEM) data are from ASTER (Advanced Spaceborne Thermal Emission and Reflection Radiometer) global DEM version 2 with $30 \mathrm{~m}$ resolution, which is available at http://www.jspacesystems.or.jp/ersdac/GDEM/E/4.html.

centuries (Kaspari et al., 2009a; Xu et al., 2010), black carbon concentrations (Ming et al., 2008; Kaspari et al., 2011), and bacterial information (Zhang et al., 2007, 2008).

Ice core stable isotopes $\left(\delta^{18} \mathrm{O}\right.$ and $\delta \mathrm{D}$, the water stable isotopic compositions expressed in $\delta$ units permil vs. VSMOW, the Vienna Standard Mean Ocean Water) are a fundamental and important proxy for temperature (i.e., temperature effect, a positive correlation between stable isotopic composition in precipitation and temperature) or precipitation (i.e., amount effect, a negative correlation between stable isotopic compo- sition in precipitation and precipitation amount) (Dansgaard, 1964). Although stable isotopes in ice cores from the central Himalayas have been investigated for more than a decade, there is a discrepancy in the interpretation of the Himalayan ice core isotopic record. According to previous studies, the DSP core isotopic record is generally interpreted as a proxy for temperature (Thompson et al., 2000b; Davis et al., 2005), whereas the ER core isotopic record is often interpreted as a proxy for the Indian summer monsoon (ISM) precipitation (Zhang et al., 2005; Kaspari et al., 2007). The DSP and ER glaciers are both located in the central Himalayas (the distance between them only $125 \mathrm{~km}$ ) and are expected to experience the same large-scale circulation systems (i.e., ISM vs. winter westerlies). Here we examine two major research questions: (1) why do the distinct interpretations of the stable isotopic records from the two cores occur? (2) Are there any undiscovered regional or local factors to justify the different interpretations?

\section{Large-scale atmospheric circulation systems and local topographic features in the central Himalayas}

\subsection{Large-scale atmospheric circulation systems}

The Himalayas, the world's highest mountains, are located on the southern edge of the Tibetan Plateau (TP), with a total length of $\sim 2500 \mathrm{~km}$ from Mt. Nanga Parbat in the west to Mt. Namjagbarwa in the east. The Himalayas intercept considerable moisture due to the topographic blocking effect. During the ISM season (June to September), the ISM transports large amounts of water vapor from the Indian Ocean to the Himalayas and the southern TP via two monsoon moisture trajectories: one from the Indian Ocean across the Arabian Sea, and along the Indian River valley to the western Himalayas and TP, and the other from the Bay of Bengal moving northward to the eastern Himalayas and TP along the Brahmaputra River valley (Liu, 1989; Lin and Wu, 1990) (Fig. 1a). During the non-summer-monsoon season (October to May), the westerlies bifurcate into the northern and southern branches around the TP due to its topographic blocking (Fig. 1a), the latter affecting the Himalayas and southern TP (Wei and Gasse, 1999). Wintertime precipitation in the Himalayas is related to vapor transport by the southern branch (Yihui and Zunya, 2008).

\subsection{Local topographic features}

The Himalayan ranges appear as a gigantic crescent situated on the southern fringe of the TP, which can be divided into four parallel mountain belts from south to north: (1) the outer Himalayas, the sub-Himalayas, the Shivaliks hills, or the foothill zone, forming the southernmost belt of the Himalayan range bordered to the south by the Indo-Gangetic Plain, having an average elevation about $900 \mathrm{ma}$ a.s.l. and a width of $40-50 \mathrm{~km}$; (2) the lesser Himalayas, the lower 
Himalayas, or Mahabharat Range (in India it is also known as Himachal Himalayas), lying north of the sub-Himalayas, having an average elevation about $3000 \mathrm{~m}$ a.s.l. and a width of $60-80 \mathrm{~km}$; (3) the greater Himalayas, the higher Himalayas, or the Great Himalayan Range (in India it is also known as Himadri Himalayas), the longest, highest, and most continuous belt in the Himalayan system, lying above the snow line with an average elevation of more than $6100 \mathrm{~m}$ a.s.l. and a width about $25 \mathrm{~km}$; and (4) the transHimalayas or the Tibetan Himalayas, the most northerly ranges of the Himalayas in the southern part of the Tibet Autonomous Region of China, bounded by the Kailas (southwest), Nganglong Kangri (north), and Nyainqêntanglha (southeast) mountain ranges and by the Brahmaputra River (south), having an average elevation about $5300 \mathrm{~m}$ a.s.l. and $225 \mathrm{~km}$ wide in the center, narrowing to a $32 \mathrm{~km}$ width at the eastern and western ends (Pascoe, 1950; Menon, 1954).

From the west to east, the Himalayas are divided broadly into three mountainous regions based on general spatial differentiation of associated geographic elements: (1) the western Himalayas, extending along the mountain chain from western Nepal (west of the Kali River) through northwestern India and northern Pakistan, and then southwest along the mountains in the border region between Pakistan and Afghanistan, having a length about $880 \mathrm{~km}$; (2) the central Himalayas or Nepal Himalayas, lying between the Tista River in the east and the Kali River in the west, having a length about $800 \mathrm{~km}$, being characteristic of soaring heights and highest mountain peaks; and (3) the eastern Himalayas, situating between eastern Nepal (east of the Tista River) in the west and Mt. Namjagbarwa in the east, having a length about 720 km (Karan, 1966; Adams Carter, 1985).

The DSP core drilling site is located on the Mt. Shishapangma ridge, which extends in a northwest-southeast direction, facing relatively low terrains in the south and in the west (Fig. 1b). The ER core was retrieved from the East Rongbuk $\mathrm{Col}$ on the northeast ridge of Mt. Qomolangma. The very high west and southeast ridges of Mt. Qomolangma are in the south of the ER core (Fig. 1b).

\section{Data}

In 1997, three ice cores were recovered from the DSP glacier. The third one (core 3), $167.7 \mathrm{~m}$ long, was drilled to bedrock at the summit of the glacier (Thompson et al., 2000b). In this ice core, the cold season dust peaks nearly juxtapose with the enriched isotopic values. Based on seasonal oscillations of $\delta^{18} \mathrm{O}$ and dust concentration as well as the beta radioactivity peak of 1963 , the core was annually dated back to 1440 at $144 \mathrm{~m}$, with an uncertainty of $3 \mathrm{yr}$ (Thompson et al., 2000b; Davis et al., 2005). Annual $\delta^{18} \mathrm{O}$ value is calculated by average of individual $\delta^{18} \mathrm{O}$ values within a year. Annual accumulation rate record of this core was constructed using a two-parameter steady state flow model that takes into ac- count the rapid thinning of annual layers near a glacier's flow divide (Bolzan, 1985; Reeh, 1988; Davis et al., 2005). The $\sim 560 \mathrm{yr}$ records of annually averaged $\delta^{18} \mathrm{O}(1450-1996)$ and accumulation rate (1442-1996) are available from the NOAA National Climatic Data Center for Paleoclimatology (http://www.ncdc.noaa.gov/paleo/paleo.html). The ER ice core was drilled in 2002 with a depth of $108.8 \mathrm{~m}$. This ice core was annually dated to the year 1534 at the depth of $98 \mathrm{~m}$ by counting annual layers in terms of seasonal variations in $\delta^{18} \mathrm{O}$ or $\delta \mathrm{D}$, soluble ions, and trace elements (Kaspari et al., 2007). The dating was verified by the beta radioactivity peak of 1963 and major volcanic horizons. Dating uncertainties are estimated to be $\pm 0 \mathrm{yr}$ at 1963 (20 samples per year) and $\pm 5 \mathrm{yr}$ at 1534 ( 4 samples per year). Annual $\delta^{18} \mathrm{O}$ value is also calculated by average of individual $\delta^{18} \mathrm{O}$ values within a year. For correcting annual ice layer thinning with increasing the depth, Kaspari et al. (2008) developed a flow model to construct the ER core annual accumulation rates based on the annual-layer thickness data. Details about this core - including sampling processing, laboratory analysis, dating, and ice flow model for constructing annual accumulation rates can be found elsewhere (Kaspari et al., 2007, 2008).

To reveal precipitation seasonality along the Himalayas, monthly precipitation amount data from four Himalayan meteorological stations (Pali, Dingri, Nyalam, and Pulan stations; Fig. 1a) are used, available from the China Meteorological Data Sharing Service System. In order to compare the Himalayan ice records with the ISM rainfall data, the instrumental summer monsoon rainfall series of four Indian homogenous rainfall regions north of $21^{\circ} \mathrm{N}$ (i.e., NMI: northern mountainous India; NWI: northwestern India; NCI: north-central India; NEI: northeastern India) (Fig. 1a) are used since these monsoon-impacted regions are directly adjacent to the Himalayas. The ISM rainfall data during 18132006 are available from the Indian Institute of Tropical Meteorology at http://www.tropmet.res.in (Sontakke and Singh, 1996; Sontakke et al., 2008). For comparing with the Indian summer rainfall series over a same period, the DSP and ER ice-core $\delta^{18} \mathrm{O}$ and accumulation rate records beginning from 1813 are used in this paper. Lastly, in order to analyze the influence of atmospheric circulation systems on the Himalayan ice core records, the monthly reanalysis data are used, including the NCEP/NCAR reanalysis data with $2.5^{\circ} \times 2.5^{\circ}$ resolution beginning from 1948 (Kistler et al., 2001), the Global Precipitation Climatology Centre (GPCC) monthly precipitation data set beginning from 1951 with $1.0^{\circ} \times 1.0^{\circ}$ resolution, and the 20th century reanalysis data (V2) with $2.0^{\circ} \times 2.0^{\circ}$ resolution beginning from 1871 (Compo et al., 2011). The NCEP/NCAR and the 20th century reanalysis data are obtained from the NOAA/ESRL PSD (National Oceanic and Atmospheric Administration/Earth System Research Laboratory, Physical Sciences Division) at http://www.esrl.noaa.gov/psd/data/gridded/. The GPCC precipitation data are available at http://gpcc.dwd.de. 


\section{Results and discussion}

\subsection{Differences between the DSP and ER ice-core records}

Previous studies have hypothesized that the DSP core site receives most precipitation during the ISM season, and ascribed the DSP $\delta^{18} \mathrm{O}$ variations at interannual or longer timescales to air temperature changes at mean condensation level (Thompson et al., 2000b; Davis et al., 2005). For the ER core, Zhang et al. (2005) found there are no correlations between the annual ER $\delta^{18} \mathrm{O}$ record and air temperature data from more than 30 meteorological stations distributed in the north and south of the Himalayas, which suggests that the $\mathrm{ER} \delta^{18} \mathrm{O}$ record is not influenced by temperature. Later, Kaspari et al. (2007) found the annual ER $\delta \mathrm{D}$ is inversely correlated with the ISM season precipitation over the nearby region of Mt. Qomolangma, which verifies that the ER ice core isotopic composition is controlled by the amount effect. To check whether a relationship exists between the Himalayan ice core records $\left(\delta^{18} \mathrm{O}\right.$ and accumulation rate) and the ISM rainfall, we calculated correlation coefficients between the Himalayan ice core records and the Indian monsoon rainfalls over the four Indian homogenous regions in north India (NMI, NWI, NCI, and NEI), as shown in Table 1. From Table 1, we find a weak but significant positive correlation between the ER accumulation rate and the summer monsoon rainfall over the NWI region, whereas there are no correlations between the DSP accumulation rate and the Indian summer rainfalls.

In order to further discern differences between the DSP and ER ice core records, time series of the two ice cores $\delta^{18} \mathrm{O}$ and accumulation rate records are compared, as shown in Fig. 2. The trend in the DSP accumulation rate is opposite to that of the ER and the average accumulation rate at the DSP site $\left(1.28 \mathrm{mi}\right.$ i.e. $\left.\mathrm{yr}^{-1}\right)$ is almost 3 times the rate at the ER site $\left(0.44 \mathrm{~m}\right.$ i.e. $\left.\mathrm{yr}^{-1}\right)$. In addition, the DSP and ER accumulation rates show step changes: higher values (the average $1.66 \mathrm{~m}$ i.e. $\mathrm{yr}^{-1}$ ) before 1880 , and lower values (the average $1.07 \mathrm{mi}$ i.e. $\mathrm{yr}^{-1}$ ) with a significantly decreasing trend beginning from 1880 at the DSP site (Fig. 2f), but lower values (the average $0.33 \mathrm{~m}$ i.e. $\mathrm{yr}^{-1}$ ) with small variation amplitude before 1938, and higher values (the average $0.65 \mathrm{mi}$ i.e. $\mathrm{yr}^{-1}$ ) with a significantly increasing trend beginning from 1938 at the ER site (Fig. 2c). We choose the year 1880 (1938) as a boundary of the DSP (ER) accumulation step change because the DSP (ER) accumulation rate exhibited a remarkable decrease (increase) beginning from 1880 (1938). Otherwise, the increasing linear trend of the DSP $\delta^{18} \mathrm{O}$ is significant at $99 \%$ confidence level (Fig. 2g), which was interpreted as an indicator of rising temperature (Thompson et al., 2000b; Yao et al., 2006). However, such an increasing trend is not significant for the ER $\delta^{18} \mathrm{O}$ record (Fig. 2d). Furthermore, the ER $\delta^{18} \mathrm{O}$ record even shows a decreasing trend to more negative $\delta^{18} \mathrm{O}$ beginning from 1938 (Fig. 2d). The remarkable differ-

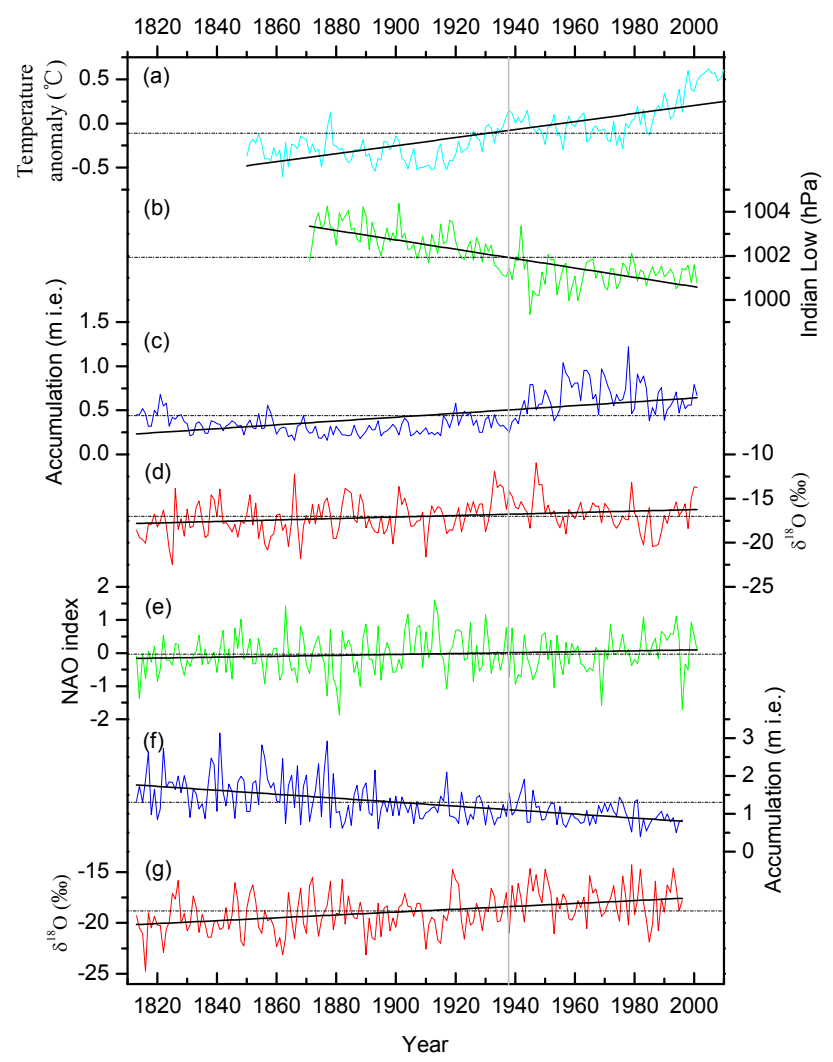

Fig. 2. Variations of (a) Northern Hemisphere annual temperature anomaly (Jones et al., 2013), (b) the Indian Low intensity, (c) the ER annual accumulation rate, (d) the annual mean ER $\delta^{18} \mathrm{O}$, (e) the non-monsoon-season (October to May) NAO index (Luterbacher et al., 2002), (f) the DSP annual accumulation rate, and (g) the annual mean DSP $\delta^{18} \mathrm{O}$ since 1813 . The short dash-dotted lines are the averages of each series, and the bold lines are their linear trends. The vertical grey line indicates the boundary year 1938 .

ence in the snow accumulation rate reconstructed from the DSP and ER cores suggests that the major precipitation origins of the two sites may differ, which could account for the different interpretations of the DSP and ER isotopic records.

\subsection{Regional precipitation patterns and their impacts on the Himalayan ice core stable isotopic record}

\subsubsection{Different precipitation seasonality along the Himalayas}

To discern the precipitation difference between the DSP and ER sites, seasonal distribution of precipitation at four weather stations - Pali $\left(27^{\circ} 44^{\prime} \mathrm{N}, 89^{\circ} 05^{\prime} \mathrm{E}\right.$, $4300 \mathrm{~m}$ a.s.l. $)$, Dingri $\left(28^{\circ} 38^{\prime} \mathrm{N}, 87^{\circ} 05^{\prime} \mathrm{E}, 4300 \mathrm{~m}\right.$ a.s.l. $)$, Nyalam $\left(28^{\circ} 11^{\prime} \mathrm{N}, 85^{\circ} 58^{\prime} \mathrm{E}, 3810 \mathrm{~m}\right.$ a.s.l.), and Pulan $\left(30^{\circ} 17^{\prime} \mathrm{N}, 81^{\circ} 15^{\prime} \mathrm{E}, 4900 \mathrm{~m}\right.$ a.s.l. $)$ - along the Himalayas (Fig. 1a) is presented in Fig. 3. The precipitation distribution over the eastern (western) Himalayas is unimodal (bimodal). Most precipitation over the eastern Himalayas occurs during 
Table 1. Pearson correlation coefficients between the Himalayan ice core records $\left(\delta^{18} \mathrm{O}\right.$ and accumulation rate) and the summer monsoon rainfall of the four Indian homogenous rainfall regions north of $21^{\circ} \mathrm{N}$ (i.e., NEI: northeastern India; NCI: north-central India; NWI: northwestern India; NMI: northern mountainous India) beginning from 1813.

\begin{tabular}{lrrrrrrrr}
\hline & NEI & NCI & NWI & NMI & ER-accum & DSP-accum & ER- $\delta^{18} \mathrm{O}$ & DSP- $\delta^{18} \mathrm{O}$ \\
\hline NEI & 1 & & & & & & & \\
NCI & $0.19^{\mathrm{b}}$ & 1 & & & & & & \\
NWI & $-0.17^{\mathrm{b}}$ & $0.46^{\mathrm{a}}$ & 1 & & & & & \\
NMI & 0.01 & $0.54^{\mathrm{a}}$ & $0.62^{\mathrm{a}}$ & 1 & & & & \\
ER-accum & -0.10 & 0.02 & $0.20^{\mathrm{b}}$ & 0.00 & 1 & & & \\
DSP-accum & 0.01 & 0.01 & -0.09 & 0.02 & $-0.31^{\mathrm{a}}$ & 1 & & \\
ER- $\delta^{18} \mathrm{O}$ & -0.12 & 0.03 & 0.02 & 0.01 & 0.01 & 0.10 & 1 & \\
DSP- ${ }^{18} \mathrm{O}$ & -0.06 & $-0.25^{\mathrm{a}}$ & -0.02 & $-0.15^{\mathrm{c}}$ & $0.28^{\mathrm{a}}$ & $-0.39^{\mathrm{a}}$ & $0.16^{\mathrm{b}}$ & 1 \\
\hline
\end{tabular}

Note: two-tailed test of significance is used.

a $99 \%$ confidence level, ${ }^{\text {b }} 95 \%$ confidence level, and c $90 \%$ confidence level. ER: East Rongbuk; DSP: Dasuopu.
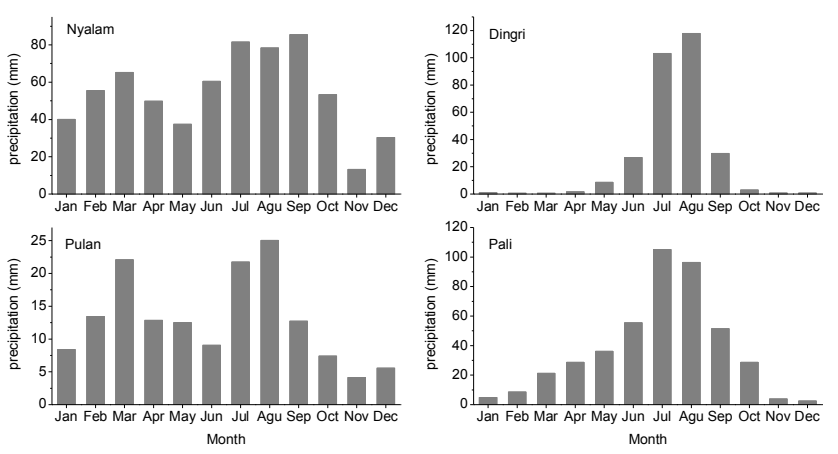

Fig. 3. Monthly long-term mean of precipitation at four weather stations along the Himalayas (Nyalam, Pulan, Dingri, and Pali). Seasonal distribution of precipitation is calculated based on the meteorological data observed from January 1973 to January 2011.

the ISM season, whereas precipitation over the western Himalayas takes place during the winter-spring and summer seasons.

To further verify precipitation seasonality along the Himalayas, spatial distribution of the non-monsoon season (October to May) precipitation ratio to annual precipitation over the study area is calculated based on the monthly long-term mean (1981-2010) precipitation data with a $0.5^{\circ} \times 0.5^{\circ}$ resolution from the GPCC (available at http://www.esrl.noaa. gov/psd/data/gridded/data.gpcc.html), as shown in Fig. 4. It is clear that the non-monsoon season precipitation ratio over the western high Himalayas $(40-80 \%)$ is higher than that over the southern and northern slopes of the Himalayas $(\leq 20 \%)$, suggesting local capture of moisture from the westerlies by the western high Himalayas. Furthermore, the non-monsoon season precipitation ratio seems to gradually decrease from the western Himalayas to Mt. Qomolangma due to moisture wastage by sequential condensation of moisture from the westerlies during its being transported eastward. Interestingly, the highest peak Mt. Qomolangma seems

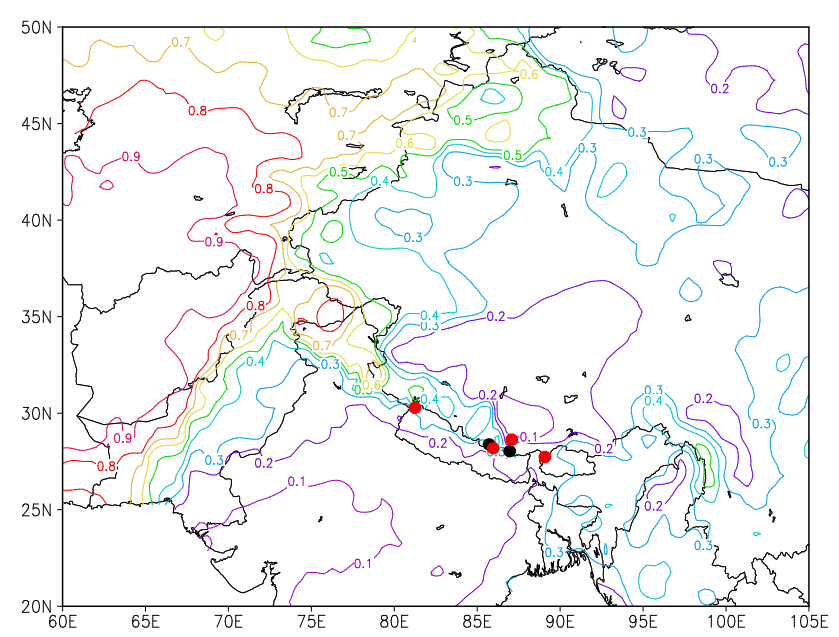

Fig. 4. Map showing the non-monsoon season precipitation ratio to annual precipitation (October-May/annual) along the Himalayas. Reanalysis data are from the monthly long-term mean (1981-2010) precipitation data with a $0.5^{\circ} \times 0.5^{\circ}$ resolution from the Global Precipitation Climatology Centre (GPCC). Filled red circles are the four weather stations along the Himalayas (from the left to right: Pulan, Nyalam, Dingri, and Pali). The non-monsoon precipitation ratios at the Himalayan stations are generally consistent with those calculated from the GPCC data. Filled black circles are DSP and ER ice cores sites (left: DSP; right: ER).

to be a boundary of the non-monsoon season precipitation ratio because west of it the non-monsoon season precipitation is high, whereas east of it the non-monsoon season precipitation ratio is rather low (Fig. 4). From this point, we can divide the Himalayas into western and eastern Himalayas by Mt. Qomolangma. According to this division, the DSP core is in the western Himalayas, while the ER core is in the eastern Himalayas, although the distance between them is only about $125 \mathrm{~km}$. 
The difference in precipitation seasonality between the western and eastern Himalayas must have an important impact on the Himalayan ice core stable isotopic records, because the stable isotopic composition in summer monsoonal precipitation is controlled by the "amount effect", whereas the stable isotopic ratio in non-summer-monsoon precipitation is dominated by the "temperature effect" (Tian et al., 2003, 2007). The non-monsoon season precipitation associated with the westerlies at Nyalam station accounts for $53 \%$ of its total annual precipitation. This site is nearby the DSP glacier; thus we speculate that the proportion of nonmonsoon season precipitation at the DSP core is also considerable. As a result, we conjecture that the stable isotopic record in the DSP core is influenced substantially by winter westerlies. On the other hand, the proportion of summertime precipitation at Dingri station accounts for more than $90 \%$ of its annual precipitation. Dingri is nearby the ER glacier; therefore we suggest that summer monsoonal precipitation dominates at the ER glacier and the ER stable isotopic record is mainly controlled by the ISM. Thus, the different seasonal distribution of precipitation between the western and eastern Himalayas is likely the main reason for the different climatological interpretations of the DSP and ER ice-core stable isotopic records. In the following two sections (Sects. 4.2.2 and 4.2.3), we further investigate how the winter westerlies and the ISM impact the DSP and ER ice-core isotopic records, respectively.

\subsubsection{Influence of winter westerlies on the DSP isotopic record}

To attest the control of winter westerlies on the DSP $\delta^{18} \mathrm{O}$, we first performed a composite analysis of moisture flux during the winter-spring season (February-April) using the monthly NCEP/NCAR reanalysis data (wind vector and specific humidity). Here, we choose February-April as the winterspring season because the non-monsoon precipitation peak occurs during these months (Fig. 3). To define the higher and lower DSP accumulation rate years, the DSP accumulation rate record was standardized by subtracting the mean and dividing by the standard deviation (SD). A year with a value $>1.0 \mathrm{SD}$ is defined as a year with higher accumulation rate, while a value $<-1.0 \mathrm{SD}$ is defined as a year with lower accumulation rate. Based on this division, there are 9 years with higher DSP accumulation rate $(1952,1953,1968$, 1970, 1972, 1975, 1976, 1980, and 1981) and 8 years with lower DSP accumulation rate $(1954,1956,1957,1965,1979$, 1982, 1984, and 1994). Figure 5 shows the composite analysis result of the winter-spring season mean moisture flux at $400 \mathrm{hPa}$ level between years with higher and lower DSP accumulation rate (higher minus lower). It is clear that moisture transport from the westerlies - originating in the northern Atlantic Ocean passing through northern Africa, Arabia, Iran, Afghanistan, Pakistan, and the Tibetan Plateau - is stronger when the DSP accumulation rate is higher, suggesting that

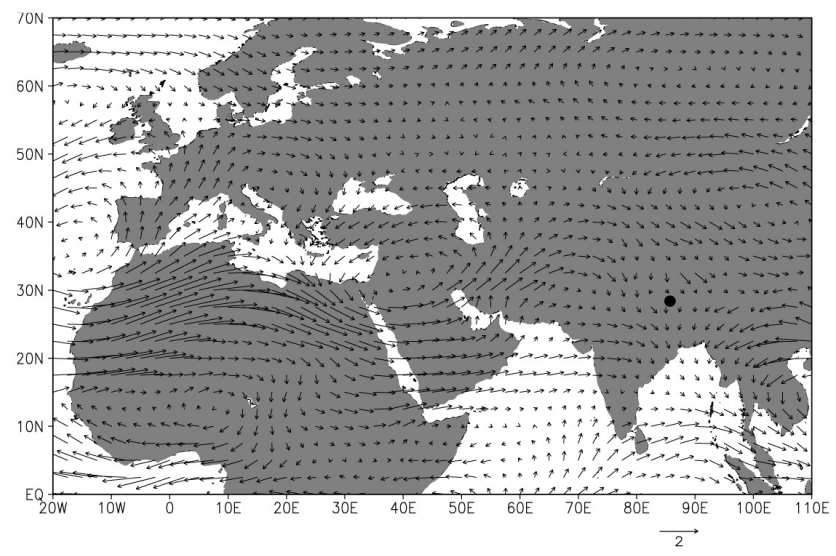

Fig. 5. Composite analysis of moisture flux (multiplying by wind vector and specific humidity) at $400 \mathrm{hPa}$ level during the winterspring season (February to April) between years with higher and lower Dasuopu accumulation rate (higher minus lower). The filled black circle indicates the DSP core drilling site.

the winter-spring season precipitation at the DSP site is significantly influenced by moisture transport from the westerlies. Moreover, we calculated the correlation between the DSP accumulation rate and the winter-spring season precipitation amount derived from the GPCC monthly precipitation data beginning from 1951. However, no significantly positive correlation was found over the western Himalayas (figure not shown), which may be due to the recently increasing contribution of the ISM precipitation to the DSP precipitation or sparse precipitation observations over the high Himalayas.

In order to verify the increasing impact of the ISM circulation on the DSP accumulation rate and $\delta^{18} \mathrm{O}$ record beginning from 1938, which we suggest in Sect. 4.4, the correlations of the DSP accumulation rate vs. summer monsoon season precipitation and the DSP $\delta^{18} \mathrm{O}$ record vs. the monsoonal precipitation were also calculated based on the GPCC monthly precipitation data beginning from 1951, as shown in Fig. 6. As we expected, we find a weak but significant positive correlation between the DSP accumulation rate and the monsoonal precipitation over the north-central India over the period of 1951-1996 (Fig. 6a). Additionally, we also find a significantly negative correlation between the DSP $\delta^{18} \mathrm{O}$ record and the summer monsoon rainfall along the southern slope of the Himalayas (Fig. 6b). Concerning the increasing contribution of the ISM precipitation to the DSP precipitation during recent decades, this will be discussed in detail in Sect. 4.4.

It is well known that the midlatitude westerlies are closely related to North Atlantic Oscillation (NAO). NAO is defined by the difference in pressure between the permanent high-pressure system located over the Azores (Azores High) and the permanent low-pressure system located over Iceland (Icelandic Low). When the NAO index is high, a large pressure difference between the two places induces stronger 
(a)

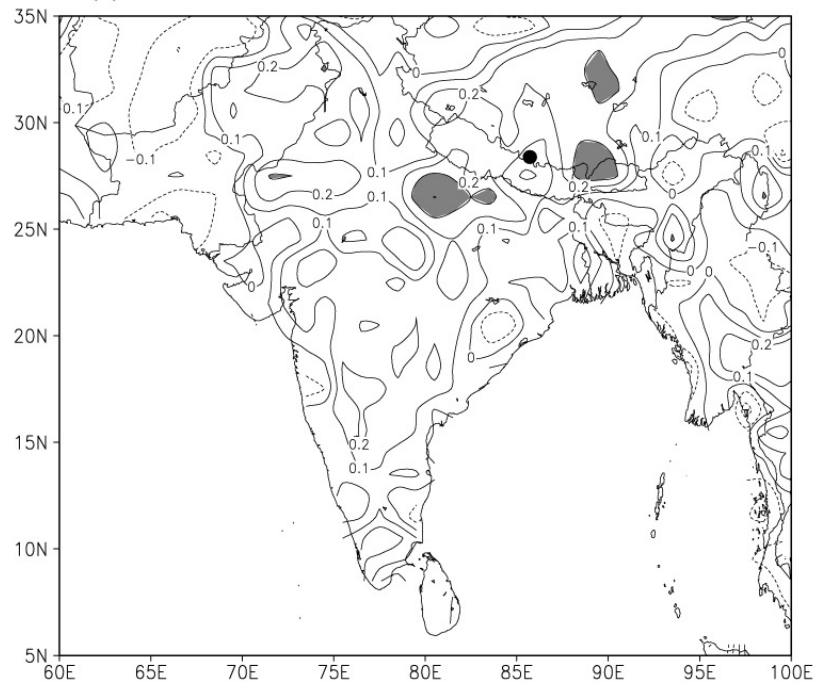

(b)

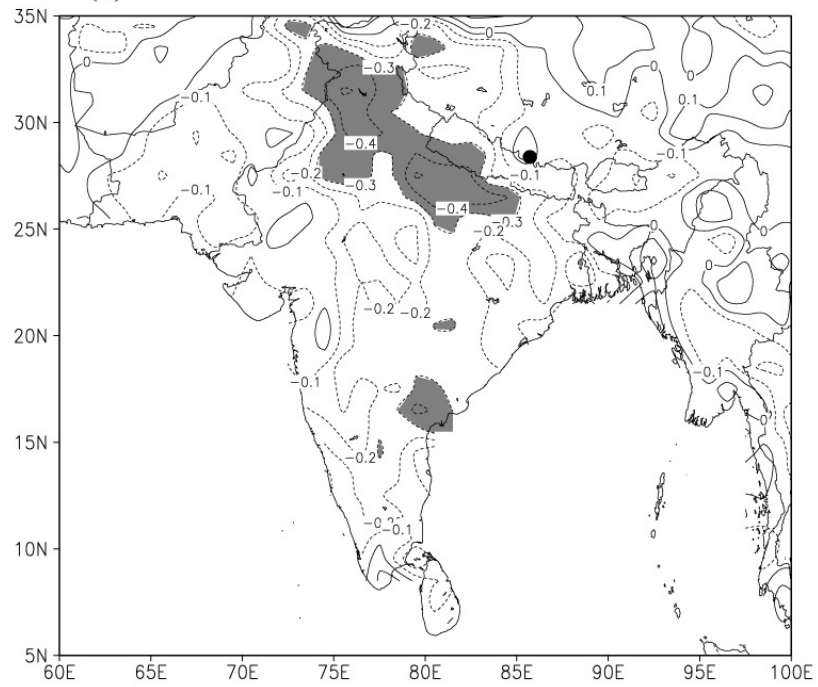

Fig. 6. Correlation coefficients of the DSP accumulation rate vs. summer monsoon season precipitation (a) and the DSP $\delta^{18} \mathrm{O}$ record vs. the monsoonal precipitation (b) over the period of 1951-1996. Grey shading indicates correlation significance at $95 \%$ confidence level. The filled black circle indicates the DSP core drilling site. Summer monsoon precipitation data are from the GPCC monthly precipitation data set from 1951 -present with $1.0^{\circ} \times 1.0^{\circ}$ resolution (available at http://gpcc.dwd.de).

westerly flow over the mid-high latitudes, leading to storm tracks shifting northward and the mid-high-latitude Europe undergoing milder winters but more frequent rainfall. When the NAO index is low, storm tracks shift southward, and the westerlies enhance over the mid-low latitudes, which results in colder winters but more rainfall in southern Europe, the Mediterranean, and northern Africa. Hence, stronger westerlies over the mid-low latitudes transport more and colder air masses eastward into the western Himalayas and bring higher snowfall there, and vice versa. We calculated the correlation between the DSP accumulation rate and an NAO index (Luterbacher et al., 2002) during the non-monsoon season beginning from 1813 and find a good negative correlation ( $r=-0.216, N=184, p=0.003$ ) (Fig. 2e and f), proving the control of the westerlies on the DSP precipitation.

As a result, stronger (weaker) westerlies over the midlow latitudes not only bring higher (lower) precipitation but also lead to a colder (warmer) temperature environment in the western Himalayas because of more (less) and colder air mass invasion. These temperature variations could lead to $\delta^{18} \mathrm{O}$ variations if the temperature effect was at play as suggested by previous studies (Thompson et al., 2000b; Davis et al., 2005). Although most researchers have suggested that the temperature effect at the DSP site is significant (Thompson et al., 2000b; Davis et al., 2005), they have not delimited a specific region where the temperature is positively correlated with the DSP $\delta^{18} \mathrm{O}$ record and only presented a good correlation between the DSP $\delta^{18} \mathrm{O}$ record and the Northern Hemisphere temperature (Thompson et al., 2000b; Davis et al., 2005). In order to determine where the temperature is correlated with the DSP $\delta^{18} \mathrm{O}$ record, we calculated the correlation between the DSP $\delta^{18} \mathrm{O}$ record and mean air temperatures during the non-monsoon season at different pressure levels deriving from the 20th century reanalysis (V2) data. Surprisingly, there is no correlation between the DSP $\delta^{18} \mathrm{O}$ record and air temperature over the regions adjacent to the DSP site. Nevertheless, we find a good positive correlation region over the Azores High area and its adjacent regions between the DSP $\delta^{18} \mathrm{O}$ record and air temperatures in the mid-low troposphere (from 850 to $300 \mathrm{hPa}$ level). Moreover, the positive correlation region is stable at different pressure levels. Because the DSP core elevation is very high (7200 m a.s.l.), we only present the correlation coefficients at $400 \mathrm{hPa}$ level as a demonstration, shown in Fig. 7. The higher (lower) air temperature over the Azores High region may imply the position of Azores High shifting northward (southward) in response to the northward (southward) shifting of the westerlies. Thus, such a positive correlation region may indicate a close relationship between the NAO and the DSP $\delta^{18} \mathrm{O}$ record. According to previous studies, there is a good positive correlation between the NAO index and the Northern Hemisphere temperature (Hurrell, 1996; Gimeno et al., 2003), which may explain why there is a good correlation between the DSP $\delta^{18} \mathrm{O}$ record and the Northern Hemisphere temperature found by previous studies (Thompson et al., 2000b; Davis et al., 2005). However, the link between westerlies and temperature does not prove that DSP $\delta^{18} \mathrm{O}$ should respond to temperature.

As a result, changes of moisture transport trajectory of winter westerlies associated with the NAO may be more important than the local air temperature in controlling the DSP $\delta^{18} \mathrm{O}$. When the mid-low-latitude winter westerlies are stronger (corresponding to a low NAO index), more vapor originating from ocean (the Atlantic Ocean) will be transported into the western Himalayas, leading to higher 


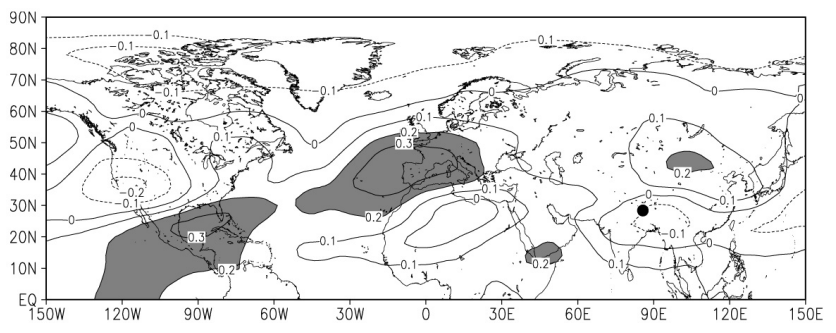

Fig. 7. Correlation coefficients between the annual mean DSP $\delta^{18} \mathrm{O}$ and mean air temperature during the non-monsoon season (October to May) at $400 \mathrm{hPa}$ level beginning from 1871 . The monthly air temperature data with $2.0^{\circ} \times 2.0^{\circ}$ resolution are from the 20th century reanalysis (V2). Grey shading indicates correlation significance at $95 \%$ confidence level. The filled black circle indicates the DSP core drilling site.

accumulation rate and lower DSP $\delta^{18} \mathrm{O}$. Conversely, when the mid-low-latitude winter westerlies are weaker (corresponding to a high NAO index), less oceanic moisture and more continental recycling vapor from northern Africa, the Mediterranean, and western Asia will be transported into the western Himalayas, resulting in lower accumulation rate and higher DSP $\delta^{18} \mathrm{O}$.

The influence of moisture from winter westerlies on isotopic composition in precipitation at the DSP site is also supported by the second-order isotopic parameter, deuterium excess, defined as d-excess $=\delta \mathrm{D}-8 \delta^{18} \mathrm{O}$ (Dansgaard, 1964). The moisture from westerlies originating in the Atlantic Ocean is enhanced by the Mediterranean evaporation during its being transported eastward. The d-excess value in the mixing vapor (Atlantic vapor plus the vapor evaporated from the Mediterranean) is generally high due to the isotopic disequilibrium between the moisture in the atmosphere and that of the Mediterranean Sea water body resulting from strong temperature contrast between them (Gat and Carmi, 1970; Rindsberger et al., 1983; Gat et al., 2003). For instance, the average value of d-excess in the 50 vapor samples collected over the Mediterranean Sea during winter of 1995 is as high as $21 \%$ (Gat et al., 2003), which is close to the average value of d-excess $(20 \%)$ in winter precipitation at Nyalam station nearby the DSP core site (Tian et al., 2005, 2007). Previous investigations suggest that the d-excess values of snow pit samples from the DSP glacier as high as $17.3 \%$ (Tian et al., 2001). The high d-excess values in precipitation at or nearby the DSP core site suggest that the influence of the westerlies is significant at the DSP site.

\subsubsection{Influence of Indian summer monsoon on the ER isotopic record}

To further verify the dominant ISM control on the ER $\delta^{18} \mathrm{O}$, we also first performed a composite analysis of moisture flux during the monsoon season using the monthly NCEP/NCAR reanalysis data. Similarly, we defined the higher and lower

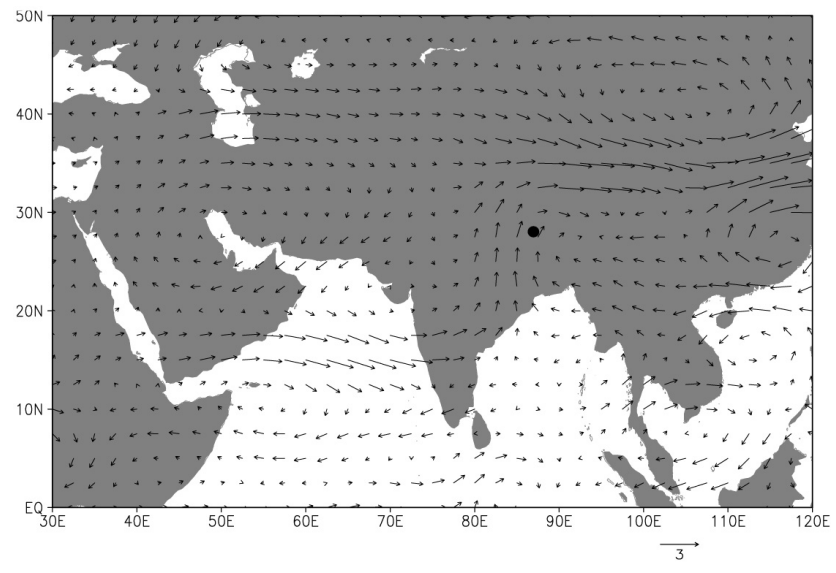

Fig. 8. Composite analysis of summer mean (June to September) moisture flux (multiplying by wind vector and specific humidity) at $400 \mathrm{hPa}$ level between years with higher and lower ER accumulation (higher minus lower). The filled black circle indicates the ER core drilling site.

ER accumulate rate years based on the same method as used for the DSP accumulation rate. There are 10 years with higher ER accumulation rate (1956, 1957, 1963, 1964, 1965, 1969, 1970, 1978, 1981, and 1983) and 8 years with lower ER accumulation rate $(1953,1954,1955,1968,1979,1985$, 1987, and 1990). Figure 8 shows the composite analysis result of the summer monsoon season mean moisture flux at $400 \mathrm{hPa}$ level between years with higher and lower ER accumulation rate (higher minus lower). It is clear that the ISM moisture flux from the Arabian Sea, via northern central India, to the central Himalayas is stronger when the ER accumulation rate is higher, and vice versa, indicating that the precipitation at the ER core site is significantly influenced by the ISM moisture transport. In addition, the correlation between the ER accumulation rate and summer monsoon season precipitation is also analyzed based on the GPCC monthly precipitation data beginning from 1951, as shown in Fig. 9a. It is clear that strongest positive correlation occurs over the northwestern region of India (i.e., the core region of the India Low), which is in agreement with the correlation analysis between the ER accumulation rate and the summer monsoon rainfalls over the four northern sub-India regions (Table 1). This suggests that precipitation at ER core site is controlled by the large-scale ISM circulation.

In order to check the influence of the ISM circulation system on precipitation at the ER core site on a longer timescale, we calculated the Indian Low intensity as the summer (June to September) mean sea level pressure over the core region of the Indian Low $\left(20-30^{\circ} \mathrm{N}, 60-90^{\circ} \mathrm{E}\right)$ based on the monthly 20th century reanalysis sea level pressure data beginning from 1871, as shown in Fig. 2b. It is clear that the Indian Low intensity is completely opposite to the ER accumulation rate: lower Indian Low pressure (in response to stronger ISM circulation) corresponds well with higher ER accumulation 
(a)

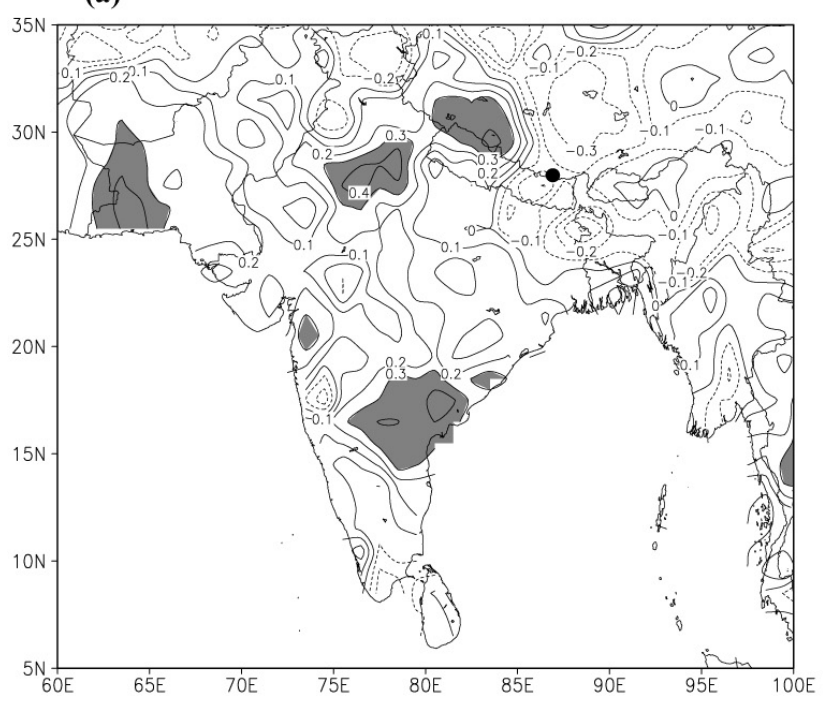

(b)

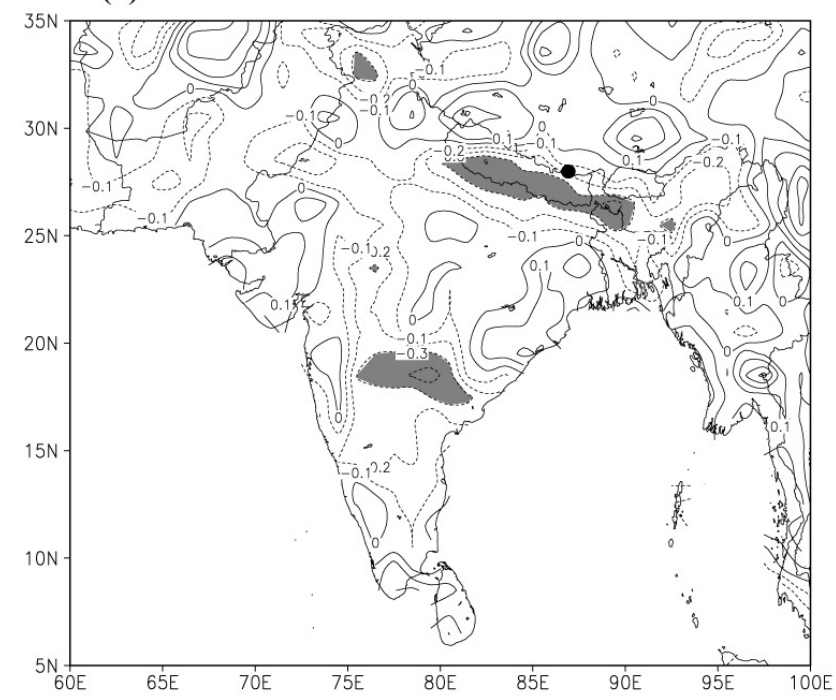

Fig. 9. Correlation coefficients of the ER accumulation rate vs. summer monsoon season precipitation (a) and the ER $\delta^{18} \mathrm{O}$ record vs. the monsoonal precipitation (b) over the period of 1951-2001. Grey shading indicates correlation significance at $95 \%$ confidence level. The filled black circle indicates the ER core drilling site. Summer monsoon precipitation data are from the GPCC monthly precipitation data set from 1951-present with $1.0^{\circ} \times 1.0^{\circ}$ resolution (available at http://gpcc.dwd.de).

rate, and vice versa (Fig. $2 \mathrm{~b}$ and c). The negative correlation between them is very significant $(r=-0.663, N=131$, $p<0.001$ ), which suggests that the influence of the ISM circulation on precipitation at the ER site is dominating.

Finally, we calculated the correlation between the ER $\delta^{18} \mathrm{O}$ record and summer monsoon season rainfall based on the GPCC monthly precipitation data beginning from 1951, as shown in Fig. 9b. We find a significantly negative correlation between the ER $\delta^{18} \mathrm{O}$ record and summer monsoon rainfall along the southern slope of the Himalayas (a long, narrow region) (Fig. 9b). Interestingly, we also find a similar such long, narrow correlation belt along the southern slope of the Himalayas between the DSP $\delta^{18} \mathrm{O}$ record and the monsoonal rainfall over the period of 1951-1996 (Fig. 6b). Note that the narrow-band negative correlation region along the southern slope of the Himalayas between the ER (DSP) $\delta^{18} \mathrm{O}$ record and the summer precipitation does not overlap with the positive correlation region in the northwest (north-central) of India between the ER (DSP) accumulation rate and the summer precipitation. This suggests that summer monsoon precipitation $\delta^{18} \mathrm{O}$ over the high Himalayas is probably controlled by precipitation processes associated with deep convective activities over the southern slope of Himalayas due to its very steep topographic gradient, where the heavy isotopes in vapor are washed out strongly by intense precipitation processes.

Relative to high d-excess values in precipitation at the DSP site, the averaged d-excess value of the ER core over the period of 1813-2001, 9.3\%o, is much lower. This lower dexcess in the ER core is probably attributed to the high humidity over the ISM moisture source region. Recently, Pang et al. (2012) also indicated that the interannual variation of $\mathrm{d}$-excess in the ER core is primarily controlled by the ISM moisture transport.

\subsection{Potential mechanisms for regional precipitation patterns}

\subsubsection{Unique geographical features associated with different precipitation seasonality along the Himalayas}

The weather systems responsible for wintertime precipitation in the western Himalayas are the western disturbances (Gupta et al., 1999). They are westerly upper-tropospheric synoptic-scale waves, originating as cut-off lows (i.e., a closed low that has become completely displaced (cut off) from and moves eastward independent of the basic westerly current) over the region adjoining the Caspian Sea (Rao, 2003). These systems intrude into the western Himalayas via the notch $\left(30-32.5^{\circ} \mathrm{N}, 70-75^{\circ} \mathrm{E}\right)$ formed by the Himalayas and the Hindu Kush mountains (Lang and Barros, 2004). Many disturbances are split into two or more secondary systems by interaction with the mountains in the western Himalayas when they migrate eastward. Snowstorms are generally related to the terrain-locked low-pressure disturbances. As a result, most moisture may precipitate over the western Himalayas because of the orographic capture of snowstorms, leading to more wintertime precipitation over the western $\mathrm{Hi}$ malayas than over the eastern Himalayas, as shown in Figs. 3 and 4.

A numerical simulation of a representative snow event suggests that significant wintertime precipitation over the central Himalayas only occurs when the western 
disturbances evolve to a favorable geometry with respect to the mountains (Lang and Barros, 2004). The DSP core is located on the Mt. Shishapangma ridge, which extends in a northwest-southeast direction. The DSP core faces relatively low terrains in the south and west (Fig. 1b), which provides a broad space for the western disturbances invading and developing. Furthermore, the northwest-southeast ridge of Mt. Shishapangma is diagonal to the flow of the westerlies, which is favorable for interacting with the western disturbances. As a consequence, the local favorable orographic conditions may result in significant wintertime precipitation at the DSP core site. On the other hand, the ER core was retrieved from the East Rongbuk Col on the northeast ridge of Mt. Qomolangma. The very high west and southeast ridges of Mt. Qomolangma (Fig. 1b) may constrain the western disturbances in the southern slope of Mt. Qomolangma ridges, which thus leads to little wintertime precipitation at the ER core site. In other words, the ER core site is equivalently situated in the leeward slope (rain shadow region) of the western disturbances. Therefore, the DSP core site is heavily influenced by the western disturbances whereas the ER core is not. The much greater accumulation rate at the DSP core site than that at the ER core site supports our conclusion.

\subsubsection{Altitudinal differences in westerly vs. monsoon moisture sources}

Previous studies have shown that most annual precipitation at low altitudes of the central Himalayas falls during the ISM season (Shrestha, 2000; Lang and Barros, 2004), while Lang and Barros (2004) found that high elevations (> $3000 \mathrm{~m}$ a.s.1.) in the central Himalayas can receive up to $40 \%$ of their annual precipitation during winter. The result seems to imply that wintertime precipitation associated with the western disturbances in the central Himalayas increases with rising elevation. The local advantageous topographic conditions may cause considerable wintertime precipitation to fall at the DSP core site (7200 $\mathrm{m}$ a.s.1.). However, the local unfavorable orographic conditions may result in little wintertime precipitation at the ER core site (6518 m a.s.l.), as mentioned above.

According to investigation on altitudinal distribution of the ISM rainfall in the central Himalayas, Dhar and Rakhecha (1981) indicated that the zones of maximum rainfall occur near the foothills at an elevation of 2000 to $2400 \mathrm{~m}$ a.s.1.. Beyond the elevation, summer monsoon rainfall decreases continuously as elevation increases until the Great Himalayan Range is reached. The result suggests that the ISM precipitation above the elevation of $2400 \mathrm{~m}$ a.s.l. decreases significantly with rising elevation in the central Himalayas. Nevertheless, the $700 \mathrm{~m}$ elevation difference between the DSP and ER ice core sites may cause little difference in summer monsoon precipitation between the two sites because the convective activity associated with the ISM precipitation can reach a high elevation.
As a result, with elevation rising in the central Himalayas, the potential increase in wintertime precipitation associated with the westerlies and the decrease in summertime precipitation related to the ISM probably lead to larger proportion of wintertime precipitation than the summertime precipitation at the DSP core site.

\subsection{Variations of winter westerlies and Indian summer monsoon during the past two centuries recorded by the Himalayan ice core accumulation}

Good correlation between the ER accumulation rate and the Indian Low intensity over the period of 1813-2001 indicates that the high ridges of Mt. Qomolangma are effective topographical barriers between the westerlies' precipitation and the ER core site. Low ER accumulation rate before 1938 corresponds to the weak Indian Low intensity and high ER accumulation rate beginning from 1938 is in response to the Indian Low intensifying (Fig. 2b and c). Furthermore, the weak (strong) ISM/low (high) ER accumulation rate seems to correspond to the relatively lower (higher) Northern Hemisphere temperature based on their trends (Fig. 2a, b, and c). This suggests that the ISM intensity over the central Himalayas may weaken in a cold climate and intensify in a warm climate. The overall increase trend of the ER accumulation rate during the past $200 \mathrm{yr}$ may reflect the ISM circulation intensifying from the Little Ice Age (LIA) cold climate to the today's global warming climate. Global circulation models also predict an increase of the summer monsoon precipitation in High Asia as a consequence of global warming (Meehl and Washington, 1993; Hu et al., 2000).

In comparison with the contribution of ISM precipitation to precipitation at the DSP site, the contribution of winter westerlies may be more important. Although there exists a $700 \mathrm{~m}$ elevation difference between the DSP and ER sites, the difference in summer monsoon precipitation between the two sites may be small, as the convective system associated with the ISM precipitation can reach a high elevation. We therefore suppose the summer precipitation amount at the DSP site equals that at the ER site. In addition, we assume the non-monsoon precipitation ratio to annual precipitation at the ER site is $20 \%$ based on the result in Fig. 4. Based on the above assumptions, we can calculate the contribution of the westerlies to precipitation at the DSP site using the ER accumulation rate data. For instance, the average DSP accumulation rate is $1.66 \mathrm{mi}$ i.e. $\mathrm{yr}^{-1}$ and the average ER accumulation rate is $0.34 \mathrm{mi}$.e. $\mathrm{yr}^{-1}$ over the period of 1813-1879; correspondingly, the proportion of precipitation associated with the westerlies at the DSP site is about $84 \%$. Similarly, the proportion is $78 \%$ over the period of $1880-1937$, and $48 \%$ over the period of $1938-1996$. It is noteworthy that the proportion of the westerlies' precipitation at the DSP site during the period 1938-1996 is comparable with the non-monsoon precipitation ratio to annual precipitation $(53 \%)$ at Nyalam weather station, suggesting that 
our estimation of the contribution of the westerlies to DSP precipitation is likely reliable. The very high DSP accumulation rate/proportion of the westerlies' precipitation over the period of 1813-1879 indicates that the westerlies' intensity over the central Himalayas is strong under the condition of the latter part of the LIA cold climate (Fig. 2a and f). The relatively low DSP accumulation rate and evident decrease of the proportion of the westerlies' precipitation over the period of 1938-1996 suggest that the westerlies' intensity over the central Himalayas is weak under the condition of the today's global warming climate (Fig. 2a and f). The general decrease trend of the proportion of the westerlies' precipitation at the DSP site over the past two centuries may reflect the gradual decrease of the westerlies' intensity over the central Himalayas, which may correspond to gradually northward shifting of the midlatitude westerlies due to global warming since the end of the LIA. Observed significant increases in high-latitude cyclone frequency and intensity (McCabe et al., 2001 ) as well as the upward trend in the NAO index (Thompson et al., 2000a) during the past several decades both indicate the northward shifting of the midlatitude westerlies due to recently significant global warming. The ECHAM4OPYC 3 coupled general circulation model also produces a significantly strengthened annual-mean meridional pressure gradient over the North Atlantic associated with projected global warming, also indicating the northward shift of the midlatitude westerlies (Hu and $\mathrm{Wu}, 2004)$.

The negative correlation between the DSP and ER accumulation rates (Table 1) and their opposite linear trends (Fig. $2 \mathrm{c}$ and $\mathrm{f}$ ) during the past two centuries are likely indicative of interplay between the winter westerlies and the ISM, as indicated by An et al. (2012). More recently, Joswiak et al. (2013) found evidence of interplay between the westerlies and the ISM based on an ice core d-excess record from the Tanggula Mountains in the central Tibetan Plateau. They indicated that a relatively greater contribution of moisture from the westerlies prior to the 1940s and an increase in the contribution of the ISM moisture after the 1940s, which are consistent with our results. In addition, Yao et al. (2012) found that the precipitation in the Himalayas associated with the ISM has been decreasing during the past three decades (19792010), while the precipitation in the eastern Pamir related to the westerlies has been strengthening. In Fig. 2c, the ER accumulation rate also shows a significantly decreasing trend beginning from the late 1970s. However, the DSP accumulation rate does not exhibit an increasing trend beginning from the late 1970s, which is likely due to the evident decrease of the ISM precipitation over this region during this period.

\section{Conclusions}

Local favorable terrain conditions cause the DSP core site receive more precipitation from winter westerlies. Stronger winter westerlies over the mid-low latitudes transport more and colder vapor into the western Himalayas and lead to higher DSP accumulation rate and lower $\delta^{18} \mathrm{O}$ value, and vice versa. However, the ER core site receives more precipitation from the ISM due to moisture from the westerlies being shielded by the high ridges of Mt. Qomolangma, which causes the ER $\delta^{18} \mathrm{O}$ record to show a significant amount effect. As a result, the past different interpretations of the stable isotopic records from the DSP and ER core sites may not be incompatible, which can be explained by the contrasting precipitation seasonality at the two sites. Nevertheless, the conclusions of the paper are only representative of the two specific Himalayan ice core locations, which are not applicable to other low-latitude ice cores.

Acknowledgements. This work was jointly supported, in China, by the National Natural Science Foundation of China (41330526, 41171052, and 41321062), National Basic Research Program of China (2010CB951401), the Chinese Academy of Sciences (XDB03030101-4), and the Fundamental Research Funds for the Central Universities (1082020904), and, in United States, by the US National Science Foundation (ATM 0139491 and ATM0754644). We are grateful to many scientists, technicians, students, and porters for their hard work in the field. Special thanks are given to anonymous reviewers for their constructive comments. We also thank Y. Wang for drawing the three-dimensional topographic maps of the Dasuopu and East Rongbuk glaciers.

Edited by: A. N. LeGrande

\section{References}

Adams Carter, H.: Classification of the Himalaya, Am. Alp. J., 27, 109-141, 1985.

An, Z., Colman, S. M., Zhou, W., Li, X., Brown, E. T., Timothy Jull, A. J., Cai, Y., Huang, Y., Lu, X., Chang, H., Song, Y., Sun, Y., Xu, H., Liu, W., Jin, Z., Liu, X., Cheng, P., Liu, Y., Ai, L., Li, X., Yan, L., Shi, Z., Wang, X., Wu, F., Qiang, X., Dong, J., Lu, F., and $\mathrm{Xu}, \mathrm{X}$.: Interplay between the Westerlies and Asian monsoon recorded in Lake Qinghai sediments since $32 \mathrm{ka}$, Scientific Reports, 2, 619, doi:10.1038/srep00619, 2012.

Bolzan, J. F.: Ice flow at the Dome C ice divide based on a deep temperature profile, J. Geophys. Res., 90, 8111-8124, 1985.

Compo, G. P., Whitaker, J. S., Sardeshmukh, P. D., Matsui, N., Allan, R. J., Yin, X., Gleason, B. E., Vose, R. S., Rutledge, G., Bessemoulin, P., Brönnimann, S., Brunet, M., Crouthamel, R. I., Grant, A. N., Groisman, P. Y., Jones, P. D., Kruk, M., Kruger, A. C., Marshall, G. J., Maugeri, M., Mok, H. Y., Nordli, Ø., Ross, T. F., Trigo, R. M., Wang, X. L., Woodruff, S. D., and Worley, S. J.: The Twentieth Century Reanalysis Project, Q. J. Roy. Meteor. Soc., 137, 1-28, doi:10.1002/qj.776, 2011.

Dansgaard, W.: Stable isotopes in precipitation, Tellus, 16, 436468, 1964.

Davis, M. E., Thompson, L. G., Yao, T., and Wang, N.: Forcing of the Asian monsoon on the Tibetan Plateau: Evidence from highresolution ice core and tropical coral records, J. Geophys. Res., 110, D04101, doi:10.1029/2004JD004933, 2005. 
Dhar, O. N. and Rakhecha, P. R.: The effect of elevation on monsoon rainfall distribution in the central Himalayas, in Monsoon dynamics, edited by: Lighthill, J. and Pearce, R. P., New York, Cambridge University Press, 253-260, 1981.

Duan, K., Yao, T., and Thompson, L. G.: Low-frequency of southern Asian monsoon variability using a 295-year record from the Dasuopu ice core in the central Himalayas, Geophys. Res. Lett., 31, L16209, doi:10.1029/2004GL020015, 2004.

Duan, K., Thompson, L. G., Yao, T., Davis, M. E., and MosleyThompson, E.: A 1000 year history of atmospheric sulfate concentrations in southern Asia as recorded by a Himalayan ice core, Geophys. Res. Lett., 34, L01810, doi:10.1029/2006GL027456, 2007.

Gat, J. R. and Carmi, I.: Evolution of the isotopic composition of atmospheric waters in the Mediterranean Sea area, J. Geophys. Res., 75, 3039-3048, 1970.

Gat, J. R., Klein, B., Kushnir, Y., Roether, W., Wernli, H., Yam, R., and Shemesh, A.: Isotope composition of air moisture over the Mediterranean Sea: An index of the air-sea interaction pattern, Tellus B, 55, 953-965, 2003.

Gimeno, L., Torre, L., Nieto, R., García, R., Hernández, E., and Ribera, P.: Changes in the relationship NAO-Northern hemisphere temperature due to solar activity, Earth Planet. Sc. Lett., 206, 1520, 2003.

Gupta, A., Rathore, L. S., Singh, S. V., and Mendiratta, N.: Performance of a global circulation model in predicting the winter systems and associated precipitation over North West India during 1994-97, in: The Himalayan Environment, edited by: Dash, S. K. and Bahadur, J., New Age International, 123-138, 1999.

Hong, S., Lee, K., Hou, S., Hur, S., Ren, J., Burn, L., Rosman, K., Barbante, C., and Boutron, C.: An 800-year record of atmospheric As, Mo, Sn, and Sb deposition in central Asia in highaltitude ice cores from Mt. Qomolangma (Everest), Himalayas, Environ. Sci. Technol., 43, 8060-8065, 2009.

Hou, S., Qin, D., Wake, C. P., Mayewski, P. A., Ren, J., and Yang, Q.: Climatological significance of ice core net-accumulation record at Mt. Qomolangma (Everest), Chinese Sci. Bull., 45, 259-264, 2000.

Hou, S., Qin, D., Zhang, D., Kang, S., Mayewski, P. A., and Wake, C. P.: A 154a high resolution ammonium record from the Rongbuk Glacier, north slope of Mt. Qomolangma (Everest), TibetHimal region, Atmos. Environ., 37, 721-729, 2003.

Hou, S., Qin, D., Jouzel, J., Masson-Delmotte, V., von Grafenstein, U., Landais, A., Caillon, N., and Chappellaz, J.: Age of Himalayan bottom ice cores, J. Glaciol., 50, 467-468, 2004.

Hou, S., Chappellaz, J., Jouzel, J., Chu, P. C., Masson-Delmotte, V., Qin, D., Raynaud, D., Mayewski, P. A., Lipenkov, V. Y., and Kang, S.: Summer temperature trend over the past two millennia using air content in Himalayan ice, Clim. Past, 3, 89-95, doi:10.5194/cp-3-89-2007, 2007.

$\mathrm{Hu}, \mathrm{Z}$. Z. and $\mathrm{Wu}, \mathrm{Z}$.: The intensification and shift of the annual North Atlantic Oscillation in a global warming scenario simulation, Tellus A, 56, 112-124, 2004.

$\mathrm{Hu}, \mathrm{Z}$. Z., Latif, M., Roeckner, E., and Bengtsson, L.: Intensified Asian summer monsoon and its variability in a coupled model forced by increasing greenhouse gas concentrations, Geophys. Res. Lett., 27, 2681-2684, 2000.
Hurrell, J. W.: Influence of variations in extratropical wintertime teleconnections on Norther Hemisphere temperature, Geophys. Res. Lett., 23, 665-668, 1996.

Jones, P. D., Parker, D. E., Osborn, T. J., and Briffa, K. R.: Global and hemispheric temperature anomalies-land and marine instrumental records, in: Trends: A Compendium of Data on Global Change. Carbon Dioxide Information Analysis Center, Oak Ridge National Laboratory, US Department of Energy, Oak Ridge, Tenn., USA. doi:10.3334/CDIAC/cli.002, 2013.

Joswiak, D. R., Yao, T., Wu, G., Tian, L., and Xu, B.: Icecore evidence of westerly and monsoon moisture contributions in the central Tibetan Plateau, J. Glaciol., 59, 56-66, doi:10.3189/2013JoG12J035, 2013.

Karan, P. P.: Geographic regions of the Himalayas, Bulletin of Tibetology, 3, 5-25, 1966.

Kaspari, S., Mayewski, P. A., Kang, S., Sneed, S., Hou, S., Hooke, R., Kreutz, K., Introne, D., Handley, M., Maasch, K., Qin, D., and Ren, J.: Reduction in northward incursions of the South Asian monsoon since 1400 AD inferred from a Mt. Everest ice core, Geophy. Res. Lett., 34, L16701, doi:10.1029/2007GL030440, 2007.

Kaspari, S., Hooke, R., Mayewski, P. A., Kang, S., Hou, S., and Qin, D.: Snow accumulation rate on Mt. Everest: synchroneity with sites across the Tibetan Plateau on 50-100 year timescales, J. Glaciol., 54, 343-352, 2008.

Kaspari, S., Mayewski, P. A., Handley, M., Kang, S., Hou, S., Sneed, S., Maasch, K., and Qin, D.: A High-Resolution Record of Atmospheric Dust Composition and Variability Since 1650 AD from a Mt. Everest Ice Core, J. Climate, 22, 3910-3925, doi:10.1175/2009JCLI2518.1, 2009a.

Kaspari, S., Mayewski, P. A., Handley, M., Kang, S., Sneed, S., Hou, S., and Qin, D.: Recent Increases in Atmospheric Concentrations of $\mathrm{Bi}, \mathrm{U}, \mathrm{Cs}, \mathrm{S}$ and $\mathrm{Ca}$ from a 350-Year Mt. Everest Ice Core Record, J. Geophys. Res., 114, D04302, doi:10.1029/2008JD011088, 2009b.

Kaspari, S., Schwikowski, M., Gysel, M., Flanner, M. G., Kang, S., Hou, S., and Mayewski, P. A.: Recent increase in black carbon concentrations from a Mt. Everest ice core spanning 1860-2000 AD, Geophy. Res. Lett., 38, L04703, doi:10.1029/2010GL046096, 2011.

Kistler, R., Kalnay, E., Collins, W., Saha, S., White, G., Woollen, J., Chelliah, M., Ebisuzaki, W., Kanamitsu, M., Kousky, V., van den Dool, H., Jenne, R., and Fiorino, M.: The NCEP-NCAR 50year reanalysis: monthly means CD-ROM and documentation, B. Am. Meteorol. Soc., 82, 247-268, 2001.

Lang, T. J. and Barros, A. P.: Winter storms in the central Himalayas, J. Meteorol. Soc. Jpn., 82, 829-844, 2004.

Lin, Z. and Wu, X.: A preliminary analysis about the tracks of moisture transport on the Qinghai-Xizang Plateau, Geogr. Res., 9, 33 40, 1990 (in Chinese).

Liu, G.: Hydrometeorological characteristics of the Tibet Plateau, IAHS Publ. No. 179, Atmospheric Deposition (Proceedings of the Baltimore Symposium, May 1989), 267-280, 1989.

Luterbacher, J., Xoplaki, E., Dietrich, D., Jones, P. D., Davies, T. D., Portis, D., Gonzalez-Rouco, J. F., von Storch, H., Gyalistras, D., Casty, C., and Wanner, H.: Extending North Atlantic Oscillation Reconstructions Back to 1500, Atmos. Sci. Lett., 2, 114-124, doi:10.1006/asle.2001.0044, 2002. 
McCabe, G. J., Clark, M. P., and Serreze, M. C.: Trends in Northern Hemisphere surface cyclone frequency and intensity, J. Climate, 14, 2763-2768, 2001.

Meehl, G. A. and Washington, W. M.: South Asian summer monsoon variability in a model with doubled atmospheric carbon dioxide concentration, Science, 260, 1101-1104, 1993.

Menon, A. G. K.: Fish geography of the Himalayas, Proc. Nat. Inst. Sci. India, 22, 467-493, 1954.

Ming, J., Cachier, H., Xiao, C., Qin, D., Kang, S., Hou, S., and $\mathrm{Xu}, \mathrm{J}$. : Black carbon record based on a shallow Himalayan ice core and its climatic implications, Atmos. Chem. Phys., 8, 13431352, doi:10.5194/acp-8-1343-2008, 2008.

Pang, H., Hou, S., Kaspari, S., Mayewski, P. A., Introne, D., Masson-Delmotte, V., Jouzel, J., Li, Z., He, Y., and Qin, D.: Atmospheric circulation change in the central Himalayas indicated by a high-resolution ice core deuterium excess record, Clim. Res., 53, 1-12, 2012.

Pascoe, E. H.: A manual of the geology of India and Burma, Vol. 1 (3rd Edn.), Government of India Press, Calcutta, 485 pp., 1950.

Rao, P. L. S.: Circulation characteristics over the Himalayas during winter season, Meteorol. Atmos. Phys., 83, 19-33, 2003.

Reeh, N.: A flow-line model for calculating the surface profile and the velocity, strain-rate, and stress fields in an ice sheet, J. Glaciol., 34, 46-54, 1988.

Rindsberger, M., Magaritz, M., Carmi, I., and Gilad, D.: The relation between air mass trajectories and the water isotope composition of rain in the Mediterranean Sea area, J. Geophys. Res., 88, 43-46, 1983.

Shrestha, M. L.: Interannual variation of summer monsoon rainfall over Nepal and its relation to Southern Oscillation index, Meteorol. Atmos. Phys., 75, 21-28, 2000.

Sontakke, N. A. and Singh, N.: Longest instrumental regional and all-India summer monsoon rainfall series using optimum observations: Reconstruction and update, Holocene, 6, 315-331, 1996.

Sontakke, N. A., Singh, N., and Singh, H. N.: Instrumental period rainfall series of the Indian region (1813-2005): revised reconstruction, update and analysis, Holocene, 18, 1055-1066, 2008.

Thompson, D. W. J., Wallace, J. M., and Hegerl, G. C.: Annular modes in the extratropical circulation. Part II: trends, J. Climate, 13, 1018-1036, 2000a.

Thompson, L. G., Yao, T., Mosley-thompson, E., Davis, M. E., Henderson, K. A., and Lin, P. N.: A high-resolution millennial record of the south Asian monsoon from Himalayan ice cores, Science, 289, 1916-1919, 2000b.

Tian, L., Yao, T., Sun, W., Stievenard, M., and Jouzel, J.: Relationship between $\delta \mathrm{D}$ and $\delta^{18} \mathrm{O}$ in precipitation from north to south of the Tibetan Plateau and moisture cycling, Sci. China Ser. D, 44, 789-796, 2001.
Tian, L., Yao, T., Schuster, P. F., White, J. W. C., Ichiyanagi, K., Pendall, E., Pu, J., and Yu, W.: Oxygen-18 concentrations in recent precipitation and ice cores on the Tibetan Plateau, J. Geophys. Res., 108, 4293, doi:10.1029/2002JD002173, 2003.

Tian, L., Yao, T., White, J. W. C., Yu, W., and Wang, N.: Westerly moisture transport to the middle of Himalayas revealed from the high deuterium excess, Chinese Sci. Bull., 50, 1026-1030, 2005.

Tian, L., Yao, T., MacClune, K., White, J., Schilla, A., Vaughn, B., Vachon, R., and Ichiyanagi, K.: Stable isotopic variations in West China: A consideration of moisture sources, J. Geophys. Res., 112, D10112, doi:10.1029/2006JD007718, 2007.

Vuille, M., Werner, M., Bradley, R. S., and Keimig, F.: Stable isotopes in precipitation in the Asian monsoon region, J. Geophys. Res., 110, D23108, doi:10.1029/2005JD006022, 2005.

Wei, K. and Gasse, F.: Oxygen isotopes in lacustrine carbonates of West China revisited: implications for post glacial changes in summer monsoon circulation, Quat. Sci. Rev., 18, 1315-1334, 1999.

$\mathrm{Xu}$, B. and Yao, T.: Dasuopu ice core record of atmospheric methane over the past 2000 years, Sci. China Ser. D, 44, 689$695,2001$.

Xu, J., Hou, S., Qin, D., Kaspari, S., Mayewski, P. A., Petit, J. R., Delmonte, B., Kang, S., Ren, J., Chappellaz, J., and Hong, S.: A 108.83-m ice-core record of atmospheric dust deposition at Mt. Qomolangma (Everest), Central Himalaya, Quat. Res., 73, 3338, 2010.

Yao, T., Guo, X., Thompson L. G., Duan, K., Wang, N., Pu, J., Xu, B., Yang, X., and Sun, W.: $\delta^{18} \mathrm{O}$ record and temperature change over the past 100 years in ice cores on the Tibetan Plateau, Sci. China Ser. D, 49, 1-9, doi:10.1007/s11430-004-5096-2, 2006.

Yao, T., Thompson, L., Yang, W., Yu, W., Gao, Y., Guo, X., Yang, X., Duan, K., Zhao, H., Xu, B., Pu, J., Lu, A., Xiang, Y., Kattel, D. B., and Joswiak, D.: Different glacier status with atmospheric circulations in Tibetan Plateau and surroundings, Nat. Clim. Change, 2, 663-667, doi:10.1038/nclimate1580, 2012.

Yihui, D. and Zunya, W.: A study of rainy seasons in China, Meteorol. Atmos. Phys., 100, 121-138, doi:10.1007/s00703-008-02992, 2008

Zhang, D., Qin, D., Hou, S., Kang, S., Ren, J., and Mayewski, P. A.: Climatic significance of $\delta^{18} \mathrm{O}$ records from an $80.36 \mathrm{~m}$ ice core in the East Rongbuk Glacier, Mount Qomolangma (Everest), Sci. China Ser. D, 48, 266-272, 2005

Zhang, S., Hou, S., Ma, X., Qin, D., and Chen, T.: Culturable bacteria in Himalayan glacial ice in response to atmospheric circulation, Biogeosciences, 4, 1-9, doi:10.5194/bg-4-1-2007, 2007.

Zhang, S., Hou, S., Wu, Y., and Qin, D.: Bacteria in Himalayan glacial ice and its relationship to dust, Biogeosciences, 5, 17411750, doi:10.5194/bg-5-1741-2008, 2008. 